\title{
Sugestões do Pe. Pedro Sbardellotto para criação de reservas para os índios Xavante
}

\section{Suggestions to reservation's creation for the Xavante aboriginous by Pedro Sbardellotto}

George Lachnitt ${ }^{1}$

DOI: http://dx.doi.org/10.20435/tellus.v17i34.477

\section{APRESENTAÇÃO DO AUTOR}

Pedro Sbardelotto nasceu aos 22 de agosto 1916 em Mel, na Itália. Chegou ao Brasil em 1936 e ingressou no noviciado dos SDB. Depois de seus estudos de filosofia, começou o tirocínio em Sangradouro, MT, mas só por um ano. Depois de dois anos e meio, voltou novamente por um ano e meio para as Missões, dessa vez em Meruri.

Continuando o ciclo dos estudos, permeado de dificuldades de saúde e respondendo a necessidades emergentes, foi ordenado presbítero em 1950. Dessa vez foi trabalhar numa frente avançada, em Xavantina, onde a Fundação Brasil Central tentou firmar o progresso no interior do país e traçar as novas rodovias que possibilitassem e implantação de projetos agropecuários naquela região, até então habitada e ferrenhamente defendida pelos Xavante.

Foi em 1951, enquanto Pe. Pedro esteve ausente por motivo do Retiro, que aos 29 de janeiro apareceram os primeiros Xavante no outro lado do Rio das Mortes. Ao lado do Pe. Colbacchini, dias mais tarde atravessou o Rio das Mortes para contatos mais consistentes com os Xavante que procuraram uma convivência pacífica com os "brancos". O problema enfrentado já era onde fazer com que se firmassem numa aldeia.

Em maio de 1951, foi enviado para Santa Terezinha para estudar o lugar para construir a nova Missão. Aquela região de difícil acesso e, no tempo da enchente,

${ }^{1}$ Universidade Católica Dom Bosco (UCDB), Campo Grande, Mato Grosso do Sul, Brasil. 
em grande parte inundada não oferecia muitas condições favoráveis para isso. Coroando esse esforço, no Natal de 1953, Pe. Pedro e Pe. Higino Fasso puderam festejar a data com a presença de um grupo de Xavante. Nessa Missão, Pe. Pedro continuou até março de 1958.

Devo acrescentar que, em março de 1959, deu-se uma desavença dos Xavante da Missão com outro grupo inimigo da mesma trib, o que resultou na fuga de todos os Xavante da Missão e, sem índios na Missão, os missionários abandonaram aquela Missão até inícios de 1962.

Enquanto isso, o Pe. Pedro já tinha sido transferido para a nascente Missão de São Marcos, entre os Xavante. Tempos difíceis em que os Xavante recuperaram sua saúde e, sob a orientação dos missionários, começaram atividades agrícolas. Os vizinhos pioneiros, ainda acostumados a combater os "selvagens", não simpatizavam com os missionários que defendiam os índios e questionavam a invasão das terras, então propriedade da Missão. Foi nesse tempo que Pe. Pedro recebeu uma famosa surra que Ihe valeu 14 pontos na cabeça para restaurar o ferimentos causados. Foi, porém, um fato significativo que lhe valeu a confiança dos índios.

Depois de três anos nessa luta, foi para Araguaiana. Em 1967, voltou a Xavantina para exercer pastoral itinerante até 1977. Foi em dezembro de 1968 que se deu o primeiro de muitos encontros com o Presidente da FUNAI, Dr. José de Queiroz Campos, que executou o interesse do Ministro do Interior pela criação de cinco Reservas para os Xavante. Desse trabalho testemunham os relatórios que abaixo leremos em todos os detalhes, trabalho imprescindível para a criação das cinco Reservas Indígenas para os Xavante. Esses relatórios também comprovam que Pe. Pedro circulava sem problemas entre todos os Xavante em defesa de seus direitos.

Com um breve intervalo, trabalhou em 1982 em Sangradouro para depois se firmar em São Marcos, onde está gozando da simpatia dos Xavante, com sua idade avançada.

Pe. Georg Lachnitt 
Do: Pe. Pedro Sbardellotto

Missionário Salesiano em Xavantina MT

Observador da FUNAI no PINA

Ao: Ex.mo Sr. General José Costa Cavalcanti

DD. Ministro do Interior.

Assunto: Considerações e Sugestões

p/ Criação de Reservas p/ os índios Xavante no Estado de Mato Grosso.

\section{ORDEM DA MATÉRIA}

Introdução

I - Esboço Histórico da Tribo Xavante

II - Principais Tentativas e Malogros de Pacificação

III - Localização dos Aldeamentos Xavante em 1.949

IV - Decreto Estadual da Reserva em 1.950

V - Deslocamento dos Aldeamentos Xavante de 1.950 a 1.970

VI - Estudos para as 3 Reservas, pela FUNAI, em 1.969

VII - Decreto Ministerial de Dezembro de 1.969

VIII - Repercussão entre os Pioneiros

IX - Posição Xavante

X - Solicitação e Sugestões da Missão Salesiana

Conclusão 


\title{
Ex.mo Sr. General José Costa Cavalcanti, DD. Ministro de Estado
}

\author{
Respeitosas Saudações
}

Visitando as Missões Salesianas entre os Xavante em abril de ano findo, Vossa Ex. - vinculou-se a esta tribo com laços de simpatia e amizade, laços esses reforçados por ocasião da recepção feita pela Banda Xavante ao Presidente da República na Ilha do Bananal, em julho passado, levando V. Ex. a a externar seus sentimentos no Simpósio FUNAI-Missões Religiosas, em Brasília, em agosto de 1.969.

As elogiosas e animadoras palavras de V. Ex. a acalentaram na Missão Salesiana esperanças e ousadia para recorrer a V. Ex. a afim de que tire esta formidável tribo do impasse inacreditável em que se encontra e assim projetá-la para um futuro de realizações.

Incorporado quase de contrabando à Comitiva Ministerial pelo Dr. José de Queiroz Campos, em Aragarças, aos 21 de abril do ano passado, acompanhei V. Ex. a em visita às Missões Salesianas de Sangradouro e São Marcos, e daí ao Bananal e Xingu, seguindo depois para Brasília a pedido do Presidente da FUNAI, afim de engajar-me para uma colaboração mais estrita.

De nacionalidade italiana, vindo ao Brasil por vocação missionária em 1.936, com 20 anos de idade, já em 1.938 passei um ano em Sangradouro, e em 1.941-42 um ano e tanto em Merúri.

Nos meados de 1.950 já estava em Xavantina, na Fundação Brasil Central (F.B.C.), onde convivi por três anos com aqueles pioneiros, tendo então realizado meus primeiros contatos com os Xavante.

Após uma pausa de um ano em Araguaiana, no Natal de 1.953 fundei a primeira Missão Salesiana entre os Xavante, em Santa Terezinha, no Rio das Mortes, a 150 km ao NE de Xavantina, onde trabalhei quatro anos, deixando ao Pe. Luiz Lorenzi, ao partir, mais de 300 Xavante, sendo que tinha iniciado com exíguo grupinho de 65.

Um ano de tratamento e descanso no Estado de São Paulo, em 1.958, em fevereiro de 1.959 já estava organizando a recém-iniciada Missão de São Marcos.

Para a sobrevivência daquela Missão já em julho foi preciso ser batizado no meu sangue pelas mãos de um fazendeiro invasor, a conselho de autoridades municipais e estaduais (... dá uma pisa no padre: ele vai embora, nenhum outro terá coragem de tomar o lugar dele: vocês ficam com as terras e acabam com os índios ...). 
Mas o Padre Pedro lá ficou, e ao fim de três anos podia entregar ao Pe. Mário Panziera a Missão encaminhada e pronta para as grandes realizações que V. Ex. - testemunhou.

Marinheiro de água doce desde os tempos de Santa Terezinha, passei então, de 1.962 a 1.967, a prestar assistência religiosa e social às povoações dos Rios Araguaia e das Mortes, desde Araguaiana e Xavantina até o Rio Tapirapé.

Pude então privar com os Karajás e Tapirapés, manter contatos periódicos com os Xavante do Rio das Mortes e sua Missão e chegar por primeiro à última aldeia Xavante arredia, no Roncador.

Em 1.968 passei mais um ano em São Marcos, com Pe. Mário Panziera, ano em que tivemos a visita do então Ministro do Interior, General Augusto de Albuquerque Lima, e justamente no 9. aniversário da minha surra.

O despontar de 1.969 encontrou-me já transferido para Xavantina para a assistência religiosa àquela região, e como elo de união entre nossas Missões e os outros aldeamentos Xavante.

Quando, ao rematar a visita aos grupos indígenas dos rios Mortes, Araguaia e Xingu, V. Ex. a auspiciava uma integração humana progressiva e eficiente dos silvícolas e preconizava o entrosamento das Missões Religiosas com a FUNAI, então o Presidente da mesma engajou-me para ajudar solucionar os problemas dos Xavante dos Areões, na área de Xavantina.

Eis uns tópicos do Ofício com que me recomendava ao chefe daquele Posto: “... Por outro lado, determinou o Ministro do Interior, recentemente, mais estreito entendimento entre a FUNAI e as Missões Religiosas. Em visita feita a São Marcos e Sangradouro, teve sua Ex. a entendimento direto com os padres salesianos, para um esforço conjunto, resultando um entendimento dessa presidência com o Padre Pedro Sbardellotto, para equacionar os problemas dos Xavante dos Areões".

"Pe. Pedro conhece, há 20 anos, essas tribos e sua Congregação cedeu esse Religioso para um trabalho conjunto".

"Portador deste Oficio, está ele credenciado, como assistente da Presidência da FUNAI, para a solução dos problemas mais urgentes dessa comunidade."

Eis portanto desde quando, como e porque metido nisto, e também porque sou o signatário desta moção.

Muito embora suas divergências e rixas internas passadas e presentes, a formidável tribo Xavante é coesa e uníssona, e baldados seriam nossos trabalhos e suores se nos fechássemos nas nossas duas Missões, e não sentíssemos e não procurássemos solucionar o mais cruciante problema dos outros e dos nossos Xavante: A posse de suas terras. 


\section{ESBOÇO HISTÓRICO DA TRIBO XAVANTE}

É verdade, há uns 150 anos, os Xavante viviam, mais ou menos sossegados, em Goiás, no divisor das águas dos rios Tocantins e Araguaia. Represálias excessivas e ladroeiras dos índios; massacres em massa em recintos fechados, aí reunidos com promessas de brindes; invasão progressiva de suas terras, e mais que tudo, invasão de suas famílias com a prostituição de suas esposas e filhas em troca de miçangas, foram injustiças revoltantes para os Xavante e os impeliram a procurar os Gerais de Mato Grosso, atravessando o Rio Araguaia na altura de São José dos Bandeirantes.

De lá prosseguiram sua retirada forçada e abrigaram-se, não digo no recesso das matas, mas nos recôncavos da Serra do Roncador, protegidos pelos pantanais aquém e além do Rio das Mortes.

Até o ano 1.850 já tinham tomado posse definitivamente de suas novas terras, donos "incontestados", a rechaçar para sempre mais longe:

para o Norte os Índios Tapirapés e Caiapós

para as praias do Araguaia, ao Leste, os Karajás

para o sul os Bororos

para o Sudeste os Kajabís e Bakairís.

Aquela liberdade sem peias, aquela vastidão imensa rica em caça, frutas e peixes, imensidão que percorriam incansáveis de abril a novembro, o quanto suas pernas agüentavam, provocou na tribo uma rápida explosão demográfica e em poucos anos os 500 emigrados alcançaram alguns milhares de silvícolas rudes e audaciosos.

Os primeiros aldeamentos dividiram-se e subdividiram-se, uns por mera superpopulação, outros por rixas internas, fixando-se uns mais ao norte, nas cabeceiras do Rio São João (afluente de esquerda do Rio das Mortes), outros mais ao sul, no rio Areões de início, chegando em seguida até os rios Couto Magalhães e Culuene.

Na passagem do século, no início da Missão Salesiana entre os Bororo, a 12 km de Merúri, os Missionários eram testemunhas do pavor que os Bororo tinham desses fantasmagóricos inimigos, procedentes da região de Areões, Couto Magalhães e Culuene. 


\section{PRINCIPAIS TENTATIVAS E MALOGROS DE PACIFICAÇÃO}

Já pelo 1.914 os missionários salesianos de Merúri, preocupados pelas contínuas incursões dos Xavante em terras dos Bororos e tendo sempre alguma vítima, como por outra parte não sempre conseguiam refrear a sede de vingança em seus assistidos, foram abrir uma colônia de atração mais longe, além do Rio São Marcos, às margens do Rio das Mortes.

Labores e sacrifícios baldados, porque por algum ano os Xavante deixaram de comparecer, pois de certo receavam as represálias às suas bravuras, e eles, cultores do sistema surpresa, de certo iam surpreendendo outros confinantes em outros quadrantes.

Recuando do Rio das Mortes, fixaram os missionários seu posto avançado entre Merúri e São Marcos, mas após alguns meses já recebiam visitas não muito pacíficas dos Xavante.

Sabedora a Missão Salesiana de que os Xavante flagelavam também as margens do Araguaia e dominavam o Rio das Mortes, concebeu ela a arriscada empresa de fixar-se bem no coração da terra do terrível Índio.

1.932: dois padres e um irmão leigo salesiano atravessam a mesopotâmia que medeia entre o Araguaia e o Mortes; partindo de Cocalinho, vão plantar suas tendas às margens do Rio das Mortes, a uns 20 km ao norte da barra do Rio Pindaíba.

Durante dois longos anos de lutas e sacrifícios; de trabalhos em fazer plantações e armazenar víveres; de viagens por terra e por água perseguindo os rastos recentes, encontrando os fogos ainda acesos, nunca porém puderam enxergar um índio.

Viam-Ihes as queimadas ao longe e à beira do rio, sentiam-Ihes a presença em múltiplos lugares, mas nada de vê-los.

Só mesmo ao entardecer do dia 1. de novembro de 1.934, descendo o Rio das Mortes de motor, é que divisaram ao longe na barranca direita do rio, a uns 100 $\mathrm{km}$ ao norte do atual Posto Pimentel Barbosa, dois Xavante.

Aceleraram o motor, ancoraram frente à barranca, atravessaram o rio numa canoa, seguiram barranco acima os rastos dos índios que já tinham sumido.

Mais adentro no cerrado encontraram-se face a face os dois padres e um belo grupo de Xavante, na maioria rapazes, alguns adultos e uns meninos de 11 e 12 anos, nenhuma mulher.

Primeiro vis-a-vis, mais fatídica entrevista, pois os selvagens insatisfeitos pelos poucos brindes, em seguida massacraram os Padres. 
Outros Missionários continuaram a obra dos dois sacrificados e conseguiram, aos poucos, presenteá-los à distância e finalmente de mão para mão.

Entra então em campo o S.P.I. (Serviço de Proteção ao Índio) que teve também seus mártires na pessoa de Pimentel Barbosa e companheiros, em 1.941, mas o gelo estava quebrado, e foram-se multiplicando os contatos amistosos às margens do rio sempre hostil no hinterland.

Em 1.941 o S.P.I. abre uma segunda frente pacificadora para os Xavante na antiga colônia de atração da Missão Salesiana de Merúri, no além Rio São Marcos, mas pelo mês de março de 1.942 afoga-se no Rio São Marcos em cheia o Chefe do Posto, e o substituto poucos meses depois fecha o Posto e volta para Cuiabá, declarando por lá que dos massacres atribuídos aos Xavante deviam ser responsabilizados os Bororo dos Padres.

Em maio de 1.949 o Brigadeiro Raimundo de Vasconcelos Aboim acreditando e acreditado pela obra pacificadora do sertanista Francisco Meireles, chefe do Posto Pimentel Barbosa, homenageia e é homenageado pelos maiores da tribo, como que firmando um tratado de não agressão, e no ano seguinte, com maior aparato, chegará, hóspede ilustre, na Serra do Roncador e conseguirá licença para presentear pessoalmente as mulheres Xavante. 


\section{LOCALIZAÇÃO DOS ALDEAMENTOS XAVANTE EM 1.949}

Protagonistas desta pacificação foram uns três aldeamentos confinantes, situados nos recôncavos da Serra do Roncador, a uns 50 km rumo nordeste de São Domingos ou seja, Posto Pimentel Barbosa.

Talvez globalmente chegassem a 700 ou mais indivíduos.

A região em idioma Xavante é denominada WEDEDZÉ, e seu chefe principal era e ainda é APOENA (O Velho).

A uns 100 km mais ao norte, nas cabeceiras do Rio São João, havia outros 2 aldeamentos, perfazendo talvez um total de 400 índios, na região denominada por eles MARÃIWATSÉDÉ.

A uns 240 km para o sudeste dos aldeamentos dos WEDEDZÉ bem próximo ao Rio Couto Magalhães havia 2 aldeamentos e mais 1 à uns $50 \mathrm{~km}$ ao oeste num pequeno afluente da direita do Rio Culuene, região essa chamada por eles NORÕTSU'RÃ, com um total mais de 1.000 .

Os contatos amistosos da Pacificação-Aboim-Meireles (1.949-1950) foram com os Xavante de WEDEDZÉ, mas já em 1.949 e mais numerosas ainda em 1.950, havia representantes dos outros 2 grupos muito embora os pacificadores não o soubessem e nem sequer o suspeitassem. 


\section{DECRETO ESTADUAL DA RESERVA EM MARÇO DE 1.950}

As facas e as panelas com que foram brindados pelo branco custaram bem caro aos Xavante, pois em troca deviam ceder-Ihes, palmo a palmo, "volentes" ou "nolentes", suas terras, e não sabiam eles que ratificando o tratado de não agressão com o civilizado, assinavam a própria condenação à extinção paulatina da tribo.

A boa fé do selvícola era ludibriada e traída pela má fé talvez somente implícita e inconsciente, mas nem por isso criminosa do Pacificador.

Logo após a primeira visita do Brigadeiro Aboim, foi elaborada e apresentada uma Reserva para os Índios Xavante, ratificado pelo governador de Mato Grosso, a 28 de março de 1.950, antes portanto da chegada da FAB ao Roncador.

Os contatos amistosos tinham ocorrido tão somente com os aldeamentos WEDEDZÉ e à beira do Rio das Mortes, portanto somente a eles podia ser solicitada a cessão de parte de seus imensos domínios, e convidados a se satisfazerem com uma área mais modesta; mas, examinando o mapa da Reserva salta aos olhos que só WEDEDZÉ foi contemplado, enquanto os outros 2 grupos totalmente expoliados, sem nenhuma contemplação para suas necessidades e para suas perambulanças.

Os elaboradores da Reserva não tinham o suficiente para averiguar se os outros aldeamentos estavam ou não contidos na Reserva proposta, mas no momento preocupavam-se, por certo, em assegurar os direitos dos recém-pacificados, deixando talvez para mais tarde a reivindicação e garantia dos direitos dos que ainda estavam em pé de guerra.

Que o governo estadual (talvez secundado por não poucos do federal) se importavam bem pouco do Índio e dos direitos de índio e que sua intenção era depredá-lo por completo, mas gradativamente, para aparentar legalidade, deprende-se do Art. 2 do referido Decreto, marcando um prazo de 2 anos para o S.P.I. demarcar a área como se o índio fosse culpado das possíveis omissões de seu tutor ou, por outra, como se a incúria do S.P.I. fosse um substitutivo eficaz e suficiente das terras do índio para sobrevivência.

Deduzimos então que esse Decreto foi uma farsa, pois mal expirou o prazo, toda a esquerda do Rio das Mortes sofreu uma retaliação sem par, "in loco" ou no papel, constante reservada para toda a tribo Xavante.- Já vimos que chegavam a uns 2.200 membros os índios dos campos e cerrados. Tão somente uma área de 10.000 (dez mil) hectares (menos de 5 hectares "per-capita", quando cada pessoa duma família, mesmo recém-nascido, tem o direito de requerer 10.000 hectares) a bem à 
margem do Rio das Mortes, fronteiriça ao Posto Pimentel Barbosa, e terra alagadiça das águas, e cheia de águas estagnadas na seca.

Naquela área não havia nenhum aldeamento Xavante nem mesmo acampamento de caça, enquanto todos os aldeamentos, pacificados ou não, por Lei estavam sujeitos, mais cedo ou mais tarde, a serem palmilhados e picados pelos agrimensores. 


\section{DESLOCAMENTOS DOS ALDEAMENTOS XAVANTE DE 1.950 A 1.970}

\section{WEDEDZÉ}

a) Apoena (o velho), chefe da maior aldeia

b) Juruna, chefe do grupo menor.

c) Eribuenã, irmão do Sebastião

d) Zé Tropeiro

e) Sebastião

Enquanto isso, os representantes dos MARÃIWATSÉDÉ e NO-RÕTSU'RÃ voltavam aos seus aldeamentos ao norte e ao sudoeste e se mantinham ainda arredios, aguardando os acontecimentos:

1. - caso: fidelidade do branco ao tratado de paz; neste caso iriam se aproximando e entregando mais uma aldeia por vez.

2. caso: traição do branco; então entrariam em cena para vingar os traídos.

O grupo recém-pacificado começou freqüentar mais e mais o Posto, chegando ao ponto de estabelecer um quase-domicílio em suas instalações e imediações à margem direita do Rio das Mortes.

Rixas internas provocaram uma cisão em fins de 1.950.

Em janeiro de 1.951, apresentaram-se em Xavantina, onde operava a Fundação Brasil Central, os 3 grupos menores: Juruna, Eribuenã e Zé-Tropeiro, ficando no WEDEDZÉ tão somente o Apoena, o velho.

a) Apoena (o velho) com uns 350 índios.

Em julho de 1.956, temendo um ataque pelos Xavante de MARÃI-WATSÉDÉ, queima a aldeia e passa a morar definitivamente no Posto Pimentel Barbosa. Com isso renuncia por nada aos direitos sobre aquelas terras, continuando a desfrutá-las em suas andanças.

Por volta de 1.961 uma metade de sua aldeia, chefiada pelo seu filho Pahiri volta a atravessar o Rio das Mortes e instala-se dentro da diminuta Reserva e em 1.963 transferem-se todos para a Barreira de Areia, a 15 km de Pimentel Barbosa, rio acima, onde ainda agora se encontram.

Em todos esses anos nunca deixaram de fazer pressão sobre os invasores ilegais e legais de seu território, desde o córrego Água-Suja ao córrego Bacaba, e desde o Rio das Mortes ao alto da Serra do Roncador, na Br-79, não amolando os moradores 
fora desses limites.

É desses últimos meses o crescer da crise, e desses últimos dias o clímax da mesma, diante da pertinência e ameaças dos invasores.

\section{b) Juruna com uns 65 índios.}

Dissidente (com Eribuenã e Zé Tropeiro do velho Apoena), vem com os 2 a Xavantina em 1.951 e 1.952, mas em seguida separa-se freqüentando mais Santa Terezinha até fixar-se definitivamente, onde moravam uns sertanejos conhecidos nos tempos da Pacificação em Pimentel Barbosa.

O velho Pe. Colbacchini, antigo Missionário dos Bororo, residindo no Merúri, muitas vezes tinha tentado aproximar-se dos Xavante na região de São Marcos; para o Natal de 1.949 transfere-se a Xavantina como Capelão da Fundação Brasil Central e para aguardar a hora propicia de reabrir a Missão Santa Terezinha, suspensa pela trágica morte dos primeiros missionários, em 1.934.

Assim reabrimos a Missão na véspera do Natal de 1.953, com os 65 índios Xavante de Juruna, e no ano de 1.956 já eram mais de 300, com os que vinham espontaneamente de Pimentel Barbosa e de Xavantina.

Juruna morreu de pneumonia em março de 1.955, sucedendo-Ihe na chefia da aldeia o parente Pepetinho, falecido por sua vez durante uma caçada, na proximidade do Posto Areões em (1.964).

Os chegados de Pimentel Barbosa, relembrando velhas rixas, foram criando casos com o Pepetinho e mais tarde também Zé Tropeiro, e muitos deles já antes do ataque à Missão tinham-na abandonado ajuntando-se ao Sebastião e outros o acompanharam depois.

c) Eribuenã, chefe do maior dos 3 grupos dissidentes do Apoena(o velho).

Depois duma primeira visita em janeiro de 1.951, girovagando por mais de um ano entre Pimentel Barbosa e Santa Terezinha, em maio de 1.952 volta a Xavantina com os outros 2 grupos e 1 permanece.

O chefe da Base de Xavantina (F.B.C.) que já tinha atravessado os tratores de outro lado do Rio das Mortes e tinha encetado a Rodovia para Sete de Setembro (Xingu), consegue aldear esses 300 e tantos Xavante à beira da nova estrada, a uns $30 \mathrm{~km}$ de Xavantina.

Em seguida é abandonado pelo Juruna, que vai para Santa Terezinha. Entre 
1.953 e 1.954 Eribuenã e Zé Tropeiro têm algum encontro com os de Couto MagaIhães (NORÕTSU'RÃ) os quais obrigam os primeiros a procurar abrigo em Xavantina.

O chefe da F.B.C. consegue ainda separá-los a $30 \mathrm{~km}$ de Xavantina. Mas em junho de 1.955, quando já estavam terminando a nova aldeia, são novamente atacados pelos de Couto Magalhães e obrigados a atravessar o Rio das Mortes.

Ficam nas imediações de Xavantina até agosto de 1.956, quando são transferidos para o novo Posto de Serviço de Proteção ao Índio (SPI) na Capitariquara, no Rio das Mortes, a metade da estrada entre Xavantina e Santa Terezinha.

Eribuenã será morto por Zé-Tropeiro na Missão Protestante Ame-ricana de Areões, em junho de 1.958.

\section{d) Zé-Tropeiro}

Poucas semanas depois da transferência para Capitariquara, levando consigo quase metade dos índios, abandona definitivamente Eribuenã e ruma para Araguaiana.

Logo lá chegando, é procurado pela Missão Protestante Americana de Barra do Garças que, por uns meses, abriga a não pequena caravana numa própria chácara na encosta da Serra perto de Barra do Garças e daí, entre março e abril de 1.957, num êxodo bem organizado, leva-a para barra do Rio Areões, no Rio das Mortes.

Durante mais de anos Eribuenã, melindrado nos seus brios de chefe dum grupo dizimado por demais por esta cisão, pede, suplica, pressiona e por fim ameaça ao Zé Tropeiro, para que volte ao Capitariquara.

Este contemporiza, pacienta, mas por fim aproveita dum pernoite de Eribuenã em sua aldeia e o elimina.

Sebastião, irmão de Eribuenã, sabedor do fato, faz uma investida no Zé Tropeiro e mata uma meia dúzia.

Zé-Tropeiro então procura guarida e reforços em Santa Terezinha.

Sebastião por sua vez leva os seus de Capitariquara para perto de Pimentel Barbosa, também ele procura guarida e reforços. Encontram-se umas 2 ou 3 vezes em campo aberto, havendo baixas de ambas as partes.

Em abril de 1.959 o Sebastião com seus homens e mais outros de Apoena (o velho) assalta, ao amanhecer, a aldeia da Missão Salesiana de Santa Terezinha.

Graças à intervenção imediata e enérgica dos Salesianos e das Irmãs, houve um só morto e alguns feridos, entre estes um Padre que recebeu uma flechada no braço.

Os atacantes cederam às instâncias dos Missionários e retiraram-se, impondo aos nossos índios a condição de abandonarem a Missão e afastaram-se rumo ao sul. 
Grupos de reconhecimento mais de uma vez compareceram nas proximidades da Missão renovando ameaças de um massacre total se não cumprissem a condição imposta, tanto que Pepetinho e Zé Tropeiro abandonaram aos poucos a Missão de Santa Terezinha e até meados de 1.962 já estavam todos em Xavantina e pelo 1.963 já estava instalado o Posto Indígena Areões, em substituição à Missão Protestante Americana.

Lá estão até agora, embora no ano passado, em princípios de junho tenham transferido a aldeia mais ao interior, para fazer frente aos invasores de suas terras.

\section{e) Sebastião}

Após o ataque de Santa Terezinha, acrescido de número com os desistentes da Missão, isto é, de Pepetinho, permanece por pouco tempo nas imediações de Pimentel Barbosa. Constatada a emigração de Pepetinho e de Zé Tropeiro, para Xavantina, para distanciar-se deles passa temporada no Garapú, no Couto Magalhães, e por fim no córrego Piaba, afluente do Rio das Mortes acima de Xavantina.

Lá chegam a montar um entreposto do SPI, mas os Xavante, não satisfeitos com a relativa vizinhança do Zé Tropeiro e Pepetinho, em maio de 1.961 manda procurar o velho amigo Pe. Pedro na Missão Salesiana de São Marcos, e aceita ir para lá em agosto, o Sebastião com seus cento e mais índios Xavante.

O Sebastião e mais alguns preferiram mais tarde passar para Sangradouro. Lá estão eles nas nossas duas Missões Salesianas para Xavante, convivendo pacificamente com seus antigos inimigos.

\section{NORÕTSU'RÃ}

a) Apoena(o novo) da Lagoa

b) Dutsã e Eribuenã no Couto Magalhães

c) José do Batoví próximo ao Coluene

Ao tempo 1.949-1.950 da Pacificação dos Xavante de UIWEDE-DZÉ, no Posto Pimentel Barbosa, havia ao sudoeste de UIWEDEDZÉ, na região do Couto Magalhães, NORÕTSU'RÃ, essas 3 aldeias com um completivo de mais de 1.000 índios Xavante ainda sem qualquer contato pacífico com o branco.

\section{a) Apoena(o novo)}

Situada à margem esquerda do córrego Aldeia, afluente do rio Couto Magalhães, e a pouca distância da famosa Lagoa (com mais de 400 ms de profundidade, e o nível da água à uns 60 ms abaixo do nível de platô em que está cravada). 
A Lagoa e aldeia foram conhecidas e fotografadas já antes de 1.949 pela expedição de Brigadeiro Aboim imediatamente após sua visita às aldeias do Roncador do Pimentel Barbosa.

Talvez em 1.951 ou 1.952, enquanto em suas incursões chegavam até em Araés, perto de Xavantina, transferiam sua aldeia uns $\mathrm{km}$ mais para o interior, à margem esquerda do Rio Couto Magalhães, poucos km acima da barra do córrego Aldeia, e vários km abaixo da aldeia de Dutsã-Eribuenã.

Até o meado de 1.953, já se dera o contato amistoso com o pessoal da F.B.C. integrado pelo Pe. Colbacchini e Mestre Francisco, em Araés, e em seguida chegaram em visita a Xavantina, encontrando-se aí oficialmente com Eribuenã-Zé-Tropeiro.

Já antes e mais ainda depois desses contatos amistosos com o branco em Xavantina, é que rechaçaram repetidas vezes de sua aldeia e fustigaram repetida e implacavelmente os brancos invasores e retalhadores de seu território.

Parece que a aldeia de Apoena (o novo) não tem a lamentar nenhuma vítima nas escaramuças com os agrimensores, enquanto vários sucumbiram traiçoeiramente, por mão de Eribuenã e Sebastião, já munidos de armas de fogo.

Mas enquanto ele (Apoena) guarda à distancia de sua aldeia os teimosos agrimensores e força a retirada dos traidores irmãos de raça Eribuenã-Sebastião, outro inimigo implacável, o sarampo Ihe invade a aldeia nos anos 1.953-1.954 dizimando-lhe os componentes, forçando os sobreviventes a procurar socorro ao sud-oeste, em terras de seus tradicionais inimigos Bororo, na Missão de Merúri.

E aqui sua história vem fundir-se com a de seus vizinhos Dutsã-Eribuenã, pois esses é que vão na vanguarda pedir socorro aos padres.

\section{b) Dutsã-Eribuenã}

Dois chefes que convivem na mesma aldeia, a 2. a das três situadas na região de Couto Magalhães, NORÕTSU'RÃ, e justamente situados, em 1.950, na margem esquerda do Rio Couto Magalhães, perto da confluência das duas cabeceiras principais do mesmo.

Parece que foram eles fazer alguma investida, por volta de 1.951, nos destemidos que já atravessavam o rio das Mortes de Merúri e iam abrindo fazendas nas cabeceiras dos Rios Noedori e Couto, provocando assim nestes rudes sertanejos a sede de vingança e ânsia de eliminar os legítimos donos das terras que eles mesmos já não queriam mais abandonar.

Em março de 1952 expira o prazo dos dois anos estipulados pelo Decreto do Governo de Mato Grosso para a demarcação da Reserva dos Xavante, e então, sem 
perda de tempo, satisfeitos pela desídia do tutor legal do indígena, bem pensando em atacar por outra frente para não acordar o SPI que já bem pouco se importa com os interesses de seus tutelados, autoridades estaduais e municipais liberam a entrada dos agrimensores por esta extrema ala esquerda, os quais, acolhidos e engrossados pelos pioneiros que "engrossados" a mais parentes massacrados a vingar, numa madrugada de junho de 1.952, invadem a aldeia de Dutsã-Eribuenã, vomitando fogo com suas armas automáticas nos índios, adultos e crianças, homens e mulheres, que acordam sobressaltados, fogem sem rumo, uns ao encontro das balas que os prostram, e os outros para longe delas, levando assim mesmo muitas cravadas em suas carnes.

O medo dá-lhes pernas, e só mesmo sofreiam sua fuga aos lamentos dos feridos que não podem acompanhar.

Vão-se reunindo os atrasados, os dispersos, esperam ainda mais pelos que não aparecem, enquanto pensam as feridas dos lastimosos.

Os maiorais organizam a expedição de reconhecimento, e na aldeia já silenciosa encontram os cadáveres dumas 9 crianças, 2 mulheres e 1 homem, e este numa atitude bem insólita para os selvagens: crucificado no chão com 5 espetos de pau.

E não foi o único assalto, não foram as únicas vítimas, mas repetiram-se as emboscadas numa verdadeira sanha genocida; e lá estão no Sangradouro os homens e mulheres com os estigmas indeléveis e até mesmo de conseqüências deletéricas em seu corpo, que podem contar os horrores por que passaram, e lá perdura na região de Xavantina a fama mácabra dum senhor "Sucupira", massacrador de Xavante.

Para cúmulo de seus males e para sofreá-los na sua sede de vingança, este aldeamento também é flagelado e dizimado e prostrado pelo sarampo trazido a ele por parentes de afluentes de Coluene em visita, que o tinham ido buscar, inconscientemente, nos assolados Postos do SPI do Batovi e Simões Lopes nas suas primeiras visitas amistosas àqueles Postos.

Terminada a virulência do sarampo sobreveio em 1.955/1.956 o Eczema, trazido por parentes do norte, mas de uma forma tão generalizada e tão forte que eram uma crosta só no corpo todo.

Assim apareceram-me no dia 2 de agosto de 1.956, na Missão de Merúri, os 4 Xavante em comissão de S.O.S., pois ninguém mais podia procurar alimentos.

Eu tinha chegado no Merúri uma semana antes acompanhado do rapazinho Xavante Pedrinho, originário da Lagoa, vindos de Santa Terezinha à cavalo até Araguaiana, para ver o estado da estrada, e pelo CAN até Merúri para solicitar o caminhão da Missão para levar uma carga até a Missão de Santa Terezinha. 
E as Missões Salesianas para os Bororo, Merúri e Sangradouro, receberam de braços abertos e abrigaram, assistiram e salvaram os infelizes e escurraçados Xavante, com não poucos trabalhos e despesas e sacrifícios.

As duas aldeias vindas de Couto Magalhães numa conjunta peregrinação, de sofredores e moribundos, deixando atrás de si um rasto de sepulturas, encontrando socorro com os missionários, dividem-se de novo Dutsã-Eribuenã com seus quase 100 Xavante. Até meados de 1.957 estão abrigados na Missão Salesiana de Sangradouro.

A uns 300 km ao leste de Cuiabá, na linha telegráfica construída por Rondon, à margem do rio Sangradouro, havia uma fazenda medida pelo mesmo Rondon em fins de 1893 para venda a particular, de quem mais tarde a Missão Salesiana comprou (e mais tarde aumentou comprando mais lotes) para servir de ponte de apoio nas viagens de Cuiabá à Missão Salesiana entre os Bororo, na Colônia Sagrado Coração de Jesus, atualmente Merúri.

Mais tarde abrigaram ali também grupinhos de Bororo provenientes dos rios Vermelho e São Lourenço, porém sempre instáveis e oscilantes, e em 1.957 a Missão Salesiana prontifica todas suas instalações e abriga (mesmo sacrificando e eliminando os dois internatos para alunos civilizados das populações envolventes) este grupo de Xavante que hoje conta de mais de 400.

Apoena-Tsibupá fixam-se (uns 200) na Missão dos Bororo, no Merúri.

Em começos de 1.957 os Padres afastam-nos à 12 kms da Missão, no Córrego Fundo, destacando-Ihes um funcionário para assisti-los diariamente, e uma equipe de missionários, um ou mais dias por semana.

Finalmente em abril de 1.958 são transferidos em lugar apropriado na própria atual Missão de São Marcos, na extrema da Reserva concedida em 1.918 e ratificado em 1.921 pelo então Governador do Estado de Mato Grosso Dom Francisco de Aquino Corrêa, para usufruto dos índios Bororo, onde, acrescidos em 1.961 pelos 100 de Sebastião e pelos 300 de Tibúrcio-Bödöditu vindos da Suiá Missú, os 200 iniciais chegam agora a passar de 800 Xavante.

Se no Sangradouro os Xavante encontraram tudo pronto e não tiveram nenhuma contestação, os de São Marcos tiveram que começar 2 vezes do nada e com a oposição dos invasores desta reserva, manifestada por arregimentação de gente armada, por oferecimentos de comidas envenenadas; por organização de derrubadas de mata à revelia nas imediações, no intuito de sufocar a incipiente Missão, mas sempre defendidos, assistidos e dirigidos pelos missionários conseguiram vencer, impor-se, permanecer e realizar-se realizando. 


\section{c) Aldeamento de Coluene}

Como já visto supra, os do 3. aldeamento da Região do Couto Magalhães, NORõTSU'RÃ, situado num afluente de direita do Rio Coluene, já antes de 1.953 tinham visitado pacificamente os Postos do SPI do Batovi e Simões Lopes, e nesse ano, vendo as investidas dos agrimensores e colonizadores na região de Couto Magalhães, investidas quase sempre sangrentas, atravessaram o Coluene e repartiram-se nos 2 Postos convivendo, pacíficos, hóspedes, com os índios Bakairí, donos daquelas terras, mantendo porém sempre contato com os parentes vindo às Missões Salesianas, visitando e sendo visitados, transferindo-se não pouco, aos grupinhos ou isoladamente em épocas várias, a uma ou outra Missão.

\section{MARÃIWATSÉDÉ}
a) Tibúrcio
b) Bödöditu

Em 1.949-1950, ao tempo da Pacificação dos Xavante do UIWE-DEDZÉ, no Posto Pimentel Barbosa, havia a mais de $100 \mathrm{~km}$ ao norte deste Posto, nas cabeceiras do rio São João, afluente de esquerda do Rio das Mortes, nos contrafortes da Serra do Roncador, região chamada por eles de MA-RÃIWATSÉDÉ por estar próxima às matas do Xingu, essas 2 aldeias com mais de 400 Xavante, complexivamente, próxima uma à outra.

Enquanto seus parentes começavam a privar com o branco na região de Pimentel Barbosa, eles faziam alguma visita pacífica aos moradores de São Félix e Luciara que se aventuravam a abrir sítios e fazendinhas a algumas léguas dos 2 centros.

Porém alguma imprudência por parte dos colonizadores provocou por 2 ou 3 vezes reações violentas por parte dos Xavante, fazendo algumas mortes, e recuando novamente invisíveis e inacessíveis.

Em 1.960 os sertanejos se esparramaram bem mais pelo interior, e começa daí em diante a invasão sistemática também deste território, e entre tantos a Fazenda Suiá-Missu.

\section{a) Tibúrcio}

Pelo 1.961, devido a rixas com os Xavante do aldeamento vizinho, afasta-se mais e mais deles, e com seus 90 Xavante ruma para o norte, e quando o Sr. Ariosto da Riva fixa o lugar de sede e inicia a abertura da fazenda sobredita, os Xavante estão 
acampados a poucos $\mathrm{km}$ de distância, e após ter recebido brindes de ferramentas jogadas do avião, visitam pacificamente a sede e aí instalam-se espontânea e definitivamente (1.963).

Tibúrcio procura tirar todas as vantagens possíveis da sua condição de hospedeiro-hospedado, e é tratado e assistido o quanto possível pela administração já tão ocupada e preocupada pelos trabalhos de magna envergadura desde o começo, nas derrubadas, construções e abertura de estradas.

Um funcionário, que tinha gosto e jeito para lidar com os índios, é destacado para atendê-los e assisti-los.

Tibúrcio, chefe ainda novo dum grupo bem reduzido, aspirava tornar-se chefe de todo o grupo MARÃIWATSÉDÉ, e conseguiu o seu anseio com um golpe.

\section{b) Bödöditu}

Chefe da maior das 2 aldeias, e de boa idade, permanece no seu território, e só uns e outros de seus caçadores "engrossados" têm contatos com os sitiantes invasores, que renovam imprudências, redobrando assim a desconfiança dos índios, mantendo-os arredios.

Recebem ferramentas jogadas pelo avião da Fazenda Suiá-Missu, e outras procuram-nas no Posto Pimentel Barbosa, onde também são aconselhados e instruídos para fazerem uma pista para avião.

O Pe. Pedro, atuante naquela região desde 1.962, visita em janeiro de 1.964 a Fazenda Suiá-Missu, entretém-se com os Xavante aí abrigados, estuda com a administração o problema da aldeia ainda arredia e recebe promessas de apoio concretizado de imediato num vôo sobre o aldeiamento de Bödöditu.

Em seguida sobe de barco o Rio das Mortes e intenta a entrada a cavalo, mas não consegue chegar, porque as informações são ainda muito vagas, e então em abril consegue novamente sobrevoar a aldeia, descobrindo recentíssima pista junto à mesma, e desta vez, também de avião o ponto de partida desde a margem do rio e a rota para lá chegar.

Pretende chegar por terra primeiro, para garantir a pista que não parece muito legal.

No dia tratado ainda está em viagem e a pé (por causa dos pântanos e dos córrego sem passagens para cavaleiros), e o avião, visto o Padre a caminho certo, volta e aterriza a muito custo naquela pista de emergência, trazendo o funcionário 
e o Tibúrcio, que não perde tempo: trata de entusiasmar o Bödöditu a seguir com toda a sua gente para a fazenda Suiá-Missu.

No dia seguinte chega o Pe. Pedro que faz de tudo para convencê-los a permanecerem aí, pois viria mais tarde abrir uma Missão como em São Marcos e Sangradouro.

A volta do Padre para a beira do rio, de avião, em primeiro lugar (pois só podia decolar com 1 pessoa de cada vez) proporcionou ao Tibúrcio a oportunidade de permanecer mais tempo na aldeia e assim dar o seu golpe, convencendo o grupo a seguir daí a uns dois meses, após a colheita, quando ele viria ao seu encontro com o seu grupinho.

Foi então que o chefete consumou o golpe eliminando os 3 ou 4 líderes contrários àquela transfêrencia-abandono do próprio território.

Os 200 e mais km que medeiam entre MARÃIWATSÉDÉ e a fazenda foram palmilhados a marchas forçadas, quanto o aguentavam as mulheres carregadas de muambas, e as crianças não carregadas pelas mães, na ânsia de chegarem à "Terra Prometida"...(julho de 1.964).

A fazenda não esperava por este golpe traiçoeiro do Tibúrcio, e não podia por certo sujeitar-se a este peso e estorvo.

O funcionário ficou destacado de uma vez a tomar conta dos índios.

A rapaziada era aproveitada, livre e espontaneamente, em trabalhos da fazenda, mas a massa da população indígena não ficava por certo confinada em sua aldeia, mas "dilagava" em todas as direções.

O primeiro ano de convivência patenteou a impossibilidade de sustentar tal situação, pois a fazenda operava com centenas de trabalhadores recrutados em Mato Grosso e Goiás, de todas as camadas sociais, e na maioria da ínfima, e esse bloco de mais de 300 selvagens aldeados a somente $1 \mathrm{~km}$ da sede, não deixava de criar uma série de problemas que complicavam a já tão difícil obra dos pioneiros.

O Pe. Pedro propõe então iniciar a Missão à uns $20 \mathrm{kms}$ da sede, proposta aceita com entusiasmo pelo então Administrador Geral da Fazenda, Sr. Orlando Ometto, que prontificou toda a assistência possível bem como a doação da Reserva (uns 5.000 hectares, sendo metade de matas), dependendo tão somente da escolha do lugar pelo Padre.

Isso em fins de março de 1.965, estando o Pe. Pedro em São Paulo a tratamento de saúde, em seguida ao naufrágio ocorrido no dia 20 do mesmo mês no Rio das Mortes. 
O tratamento protelou-se até fins de junho, e quando o Padre chegou à Fazenda Suiá, o gerente local já tinha-se antecipado, escolhendo uma área a $60 \mathrm{~km}$ mais ao norte.

Num vôo de 10 minutos o Padre chegava no local escolhido, Gorgulho, onde já se achava o funcionário encarregado com uns 20 rapazes Xavante executando os trabalhos preliminares.

Na opinião do Padre o lugar era "in toto" impróprio para uma Missão, para um aldeamento estável, e os acontecimentos de 1.965 a 1.966 comprovaram essa opinião, tanto que levaram a fazenda a procurar acolhida para os índios nas Missões de São Marcos e Sangradouro, e eles mesmos optaram pela primeira.

E para lá foram transferidos os 300 e mais Xavante com avião da FAB no meado de agosto de 1.966, abandonando assim definitivamente sua região MARÃIWATSÉDÉ não muito satisfeitos, mas impelidos pelas circunstâncias e logrados nas suas expectativas quanto à "Terra Prometida" das promessas do Tibúrcio.

Em São Marcos sentiram-se hóspedes bem aceitos, mas sempre hóspedes, sem aquela liberdade de autodeterminação e de grupo independente que "ab immemorabili" desfrutavam.

Em outubro sobreveio a epidemia do sarampo, que ceifou quase a terceira parte desse grupo, quando só alguns dos antigos da Missão faleceram, e não por diferença de tratamento, mas por não possuírem reserva de defesas orgânicas estando extremamente desnutridos devido àquele ano passado no "Gorgulho", não obstante todos os esforços da fazenda para supri-los até mesmo por via aérea.

Os que escaparam à morte graças aos desvelos dos missionários e dos irmãos Xavante improvisados enfermeiros, afeiçoaram-se mais aos seus hospedeiros e entrosaram-se de uma vez na comunidade.

\section{BENEDITO}

Parente próximo de Apoena(o novo), nascido na região do Couto Magalhães, NORÕTSU'RÃ, em 1.957 ao chegar à Missão de Merúri ele era ainda rapaz solteiro.

Naquela quadra a maioria dos rapazes Xavante, sequiosos de aventuras, de ver, aprender, e ganhar, e vendo que a Missão não podia prover a tantas bocas, abriram pelo mundo afora, nas fazendas, nas turmas de estradas e alhures.

Sabedores da transferência de seus parentes para iniciar São Marcos, quase todos voltaram ao convívio tribal até pelo fim de 1.958 ou começos de 1.959 , e só um e outro voltaram mais tarde. Entre estes o Benedito. 
Trabalhando numa fazenda perto de Guiratinga, umas 2 ou 3 vezes veio visitar seus parentes trazido de avião pelo patrão que visitava uma sua incipiente fazenda além do Rio das Mortes.

Líder natural e independente, com a cabeça cheia de histórias contra os Padres das Missões (ardil usado por fazendeiros e sertanejos para desacreditar os abnegados defensores dos silvícolas, para assim mais facilmente desagregar e aniquilar os selvagens recém-pacificados), veio à Missão de São Marcos em fins de 1.961 com ares de Messias e com propósitos de divisionismo.

Aduzindo fúteis motivos, saiu da aldeia e foi morar a uns 1.500 metros mais longe, atraindo para junto de si mais duas famílias de parentes, e lá, fora das vistas dos missionários, vivia de "conluio" com os fazendeiros, já inimigos declarados dos Xavante na chegada dos mesmos à Missão.

Por 2 ou 3 anos o Pe. Mário pacientou e procurou fazer-Ihes compreender o erro e o perigo em que se metia.

Quando Pe. Mário chegou a uma atitude mais decidida, impedindo-Ihes voltar a morar na aldeia sujeitando-se ao sistema da Missão (pois vivia a reclamar toda a assistência da Missão, e tudo que produzia negociava às escondidas com sitiantes) ou procurasse outro aldeiamento de seu gosto, então lá pelos 1.965 transferiu-se para Couto Magalhães, a pouca distancia de sua antiga aldeia, mas dentro da já encaminhada Fazenda "Xavantina", só com sua exígua família no começo, e garantindo ao gerente da fazenda que não admitiria outros Xavante, mas aos poucos foi chamando outros e mais outros, até que atualmente são uns 90.

Com a volta do Benedito ao Couto Magalhães, os missionários tiveram conhecimento dos propósitos secretos dos Xavante, tanto de São Marcos como de Sangradouro, a respeito de seu antigo território, e sua vontade inabalável de lá voltar em parte, quando fosse possível serem acompanhados por missionários e missionárias. Vêem desde então as práticas dos Padres Salesianos para conhecer a antiga região da tribo e encaminhar junto ao Governo Estadual o pedido de terras para a instalação de um Posto Missionário.

É de junho de 1.967 o decreto do governador de Mato Grosso reservando para os índios Xavante sob a responsabilidade da Missão Salesiana uma área de 10.000 hectares da região do Couto Magalhães.

Os Padres pleiteavam a Reserva em outra área indicada pelos Xavante e por isso até agora não foram reconhecer-lhes os limites, aguardando uma reconsideração do caso.

Agora a sobredita Reserva consta no Cadastro Municipal de Barra do Garças como "Reserva para os Índios Xavante." 


\section{ESTUDOS PARA AS RESERVAS, PELA FUNAI, EM 1.969}

Quando em julho de 1.968 o então Ministro Albuquerque Lima visitou as Missões de Sangradouro e São Marcos, inteirou-se do maior e mais cruciante problema dos Xavante;-"......desejando, sobretudo, "voltar às suas terras, de onde foram afastados".

Isto deixou escrito no "Livro de Impressões", e à viva voz garantiu aos índios 50.000 hectares de seu antigo território do Couto recomendações ao Presidente da FUNAI para proceder sem demora ao estudo da Reserva.

O mesmo Presidente pediu à Missão Salesiana para estudar o caso e mais tarde, em setembro, recomendou-me instantemente que fosse ver, estudar e relatar a ele.

Quando em novembro pude chegar até Couto Magalhães para estudar os limites propostos pelos Xavante, fui informado que uns dias antes já tinha estado lá o Sr. Hélio Buker, delegado regional da FUNAI em Cuiabá.

Sem perda de tempo transportei-me àquela capital para saber o resultado daquela visita, e o Sr. Buker apresentou-me o mapa pronto para ser remetido a Brasília, com a descrição das 3 reservas: Couto-Magalhães, Areões e Pimentel Barbosa.

Achei exígua a Reserva Pimentel Barbosa, e grandes em demasia as outras 2, e por cúmulo a do Couto enorme mas abrangendo somente uma beiradinha das terras reivindicadas pelos índios, ficando completamente fora o que eles reclamavam de qualquer jeito, como a zona de suas antigas e da atual aldeia e as matas do babaçu.

O Sr. Hélio aduziu-me que o lugar-tenente do Benedito (este tinha vindo à Missão para solicitar a intervenção dos missionários afim de conseguir seu antigo território) tinha concordado com a delimitação proposta, e que ele Buker pretendia ficar o quanto possível dentro da Reserva criada pelo Estado em 1.950 e caducada em 1.952.

E assim pelo fim de novembro de 1.968 o Delegado Regional FUNAI de Cuiabá apresentava à Presidência da FUNAI em Brasília a proposta das 3 reservas com globalmente mais que 600.000 hectares, que porém não teriam solucionado o magno problema porque eivadas de falhas e injustiças na raiz.

Os únicos a ficarem satisfeitos, e assim mesmo não muito porque lhes tirava as verdadeiras cabeceiras do Rio Areões, eram os Xavante do Posto Areões porque incluía a área posteriormente proposta dentro duma área bem maior fechada pelos Rios Areões, das Mortes e Borecaia unindo a cabeceira do Borecaia com uma cabeceira oeste do Areões, cortando assim a estrada BR-79 e toda a frente Xavantina.

Os de Pimentel Barbosa estavam contrariadíssimos porque, fechando a área entre o Rio das Mortes e uma linha seca de cabeceira a cabeceira do Curuá e Riozinho, ficava 
de uma vez por fora toda a região de suas antigas aldeias, a que não renunciaram por nada mesmo passando a morar ao lado do Posto na margem direita do Rio das Mortes.

Contrariadíssimos também estavam os de Couto Magalhães porque por si ganhavam uma área vastíssima à direita do Couto Magalhães, era Ihes tirada a região toda da cabeceira do mesmo Rio, especialmente a banda esquerda, onde tinham suas aldeias de onde foram expulsos.

Em abril de 1.969, por ocasião da visita de V. Ex.a às Missões Salesianas de Sangradouro e São Marcos (onde V.Ex. a teve oportunidade de escutar da boca dos mesmos Xavante a reclama insistente pela devolução de suas terras), levou-me o Sr. Presidente da FUNAI a Brasília e lá apresentou-me todo o processo das sobreditas Reservas pedindo-me que examinasse e visse se era possível reduzir-lhes o tamanho, atendendo sempre às reivindicações sim, mas sobretudo às necessidades reais dos Xavante, fitando não só uma mera sobrevivência, mas um desenvolvimento progressivo mediante uma integração harmoniosa de toda a não pequena e nem indolente tribo Xavante.

Já por 2 vezes (em setembro de 1.968 e janeiro de 1.969) tinha eu solicitado à Superintendência da SUDECO e recebido formal promessa de avião para sobrevoar as regiões em questão, mas, por motivos de força maior, tudo deu em nada.

Ventilei então com o Presidente da FUNAI a possibilidade deste vôo para poder fazer um trabalho com maiores conhecimentos e eliminação de dúvidas, porém foi achado inviável e da máxima urgência apresentar a corrigida proposta de Reservas, e assim julgamos bem:

1.․ Aumentar a Reserva de Pimentel Barbosa, para abranger a região de suas aldeias do tempo da pacificação, e nos limites sempre reivindicados pelos Índios, sempre porém dentro da Reserva de 1.959, pela qual tinham sido eles e somente eles os contemplados. Uns 300.000 hectares.

2. Reduzindo à metade a Reserva de Areões, dando-Ihes um formato mais regular e não deixando atravessar a rodovia Xavantina-São Félix. Também toda dentro da Reserva de 1.950, procedendo estes Xavante, aliás, do grupo UIWEDEDZÉ de Pimentel Barbosa. Uns 120.000 hectares.

3.․ Reduzir a 1/7 (um sétimo) a Reserva Couto Magalhães incluindo-a toda dentro de limites naturais, abrangendo assim também a atual aldeia de Benedito, excluindo porém as aldeias do tempo da invasão pelos agrimensores, e toda ela fora da Reserva de 1.950, invadindo é verdade porém o menos possível a Fazenda "Xavantina". De 30.000 a 35.000 hectares. 


\section{DECRETO MINISTERIAL DE SETEMBRO DE 1.969}

Apresentada em começos de maio esta proposta pela FUNAI ao Ministério do Interior para estudo, foi aprovada e decretada pelos Ministros Militares aos 23 de setembro de 1.969, e poucos dias depois os mesmos Ministros Militares assinavam Ato que modificava o referido Decreto, modificação assim motivada por V. Ex... -"...... projeto "ora apresentado visa regular o estabelecimento da situação e dos "limites das áreas reservadas e que no Decreto 65.212 supra "mencionado, não ficaram livres de eventuais contestações. O objetivo "precípuo do Ato Modificador é, assim, impedir inúteis e prejudiciais "tendências com proprietários estabelecidos há longos anos naquelas "terras matogrossenses......" (de "O Estado de São Paulo").

A redação da proposta das Reservas por mim elaborada em maio já antes da ratificação e promulgação pelo Decreto Ministerial tinha subido modificações devido a acontecimentos posteriores e a anteriores sugestões.

A incursão dos Xavante dos Areões (29 de maio de 1.969) numa derrubada de matas obrigando os invasores a abandonarem os trabalhos e o local, e a subseqüente transladação da aldeia para lá (4 de junho) sugerira a ampliação da área naquele rumo, ainda mais para abranger também vastos buritizais e lindas e piscosas lagoas que o Zé Tropeiro diz terem sido o "habitat" de seu pai e avô nessa região por eles chamada "NORÕWEDEPA" (Areões) e reclamar como sua herança pelos menos até a rodovia Xavantina-São Félix.

Para a modificação da Reserva Pimentel Barbosa as sugestões tinham sido apresentadas pelo Sr. Euvaldo Gomes da Silva, atual chefe do Posto Areões, e antigo funcionário-intérprete na pacificação dos Xavante em Pimentel Barbosa, e conhecedor daquela região por ter chegado por terra até as aldeias da Serra do Roncador com o Brigadeiro Aboim e Francisco Meireles. 


\section{REPERCUSSÃO ENTRE OS PIONEIROS}

Essas modificações, porém, saíram tão estropiadas que confundiram os mesmos funcionários do Departamento do Patrimônio Indígena da FNI no Rio de Janeiro e alvoroçaram, sem necessidade, fazendeiros confinantes.

O alarme foi grandíssimo, mas em parte sem razão, e a parte que tinha razão para isso usou de argumentos históricos falsos, ofensivos e até mesmo contraditórios, e desde que transpareceu a notícia da criação das Reservas não faltaram ameaças à minha integridade física, aludindo mesmo à surra que levei em 1.959 em São Marcos, e que agora me dariam o resto.

\section{Reserva do Posto Pimentel Barbosa UIWEDEDZÉ}

É a Reserva que teve a contestação mais radical.

Ao norte do Posto, à margem do Rio das Mortes, tinham-se colocado vários posseiros abrindo fazendinhas e sítios, sem serem os donos das terras, esperando aparecerem os donos para chegar a um acordo.

Os Xavante foram avisando e pedindo que se retirasse para deixar livre seu território.

Uns, a contragosto é verdade, já se retiraram, e outros estão ainda esperando pelo Decreto e Demarcação, para ver o que podem receber de indenização pelas benfeitorias.

A crise maior é ao oeste, à margem da Rodovia Xavantina-São Félix, na Serra do Roncador, na região das aldeias velhas.

Lá é que os donos das terras não querem de forma nenhuma largar de mão o que compraram e projetam grandes empreendimentos, não obstante todas as advertências dos índios e do Chefe do Posto, Sr. Jamiro Batista Arantes, que já no ano passado apresentou relatório pormenorizado sobre a situação.

V. Ex. a está por certo mais bem informado do que eu sobre a ida da Polícia Federal, sobre as prisões efetuadas e o desfecho.

\section{Reserva do Posto Areões NORÕWEDEPA}

À margem do Rio das Mortes existem muitos posseiros fazendo suas plantações e criando seu gadinho enquanto não chegam os donos, outros com licença dos donos à condição de plantarem capim. 
Ao nordeste há uma fazenda bastante grande, "Dois Corações", com grandes invernadas, mas no momento abandonada e decaindo.

O mesmo Posto está dentro duma gleba que se estende Rio das Mortes abaixo e Rio Areões acima, com grandes derrubadas formadas a capim.

A parte noroeste é que foi a mais retalhada entre pequenos proprietários trabalhando ativamente e por nada dispostos a se retirarem, e foi o que levou os Xavante a comparecerem no lugar duma nova grande derrubada, no fim de maio do ano passado, e obrigar os trabalhadores a se retirarem, e sem perda de tempo transferiram para lá sua aldeia, a mais de $25 \mathrm{kms}$ da sede do Posto.

Lá é que os assisti por mais de mês, fornecendo-lhes alimentos e entusiasmando-os ao trabalho confiando numa pronta solução que até agora não veio, provocando isso mais atritos, culminando também lá com recentes prisões.

\section{Couto Magalhães NORÕTSU'RÃ}

A Reserva proposta e decretada está quase toda contida dentro dos limites da Fazenda "Xavantina" (cortando ao máximo 1/4 da fazenda).

Chamam-na de "Fazenda dos Americanos" ou do Dr. Mário, coronel reformado que a gerencia, e que diz ter começado os trabalhos preliminares em 1.958, sem vestígios de índios na região.

Vestígios recentes, acredito, pois pelo fim de 1.956 e começos de 1.957 já estavam procurando abrigo nas Missões Salesianas, mas ainda durante o 1.957 passou lá demorando-se um pouco, um grupinho de Xavante que anos antes tinham ido visitar os parentes do Pimentel Barbosa (e alguns os encontrei eu mesmo em julho de 1.955 caçando à margem direita do Rio das Mortes entre Pimentel Barbosa e Santa Terezinha) e voltaram dando uma volta pelo Garapú, onde pararam quase um ano, chegando ao Couto já não encontraram mais os parentes, e os alcançaram já nas Missões Salesianas.

Concedo, pois, que vestígios recentes não houvesse em 1.958, mas de ano e pouco mais, muitos e talvez aldeamentos não destruídos.

Já pelo 1.965, após a ida do Benedito para o Couto, os Padres foram ver o território, reconstruir um pouco a história ainda recente, e procurar pelos donos da fazenda, os Americanos, que confessaram que a contragosto chegariam a negociar, mas então a fazenda toda, pois a parte mais reclamada pelos índios era justamente o miolo, o melhor da fazenda. 
Os Padres recorreram então ao Governo de Mato Grosso, que em junho de 1.967 decretou o lote de 10.000 hectares, supramencionado.

Não era isto, ou, somente isto que os Índios queriam e que mais tarde pediram ao Gen. Albuquerque Lima (1.968) e a V.Ex.ㄹ em 1.969.

Eles reclamavam, reclamam e reclamarão enquanto não o conseguirem, a margem direita e sobretudo a margem esquerda do Rio Couto Magalhães desde as extremas de suas cabeceiras até pelos menos a confluência do córrego Aldeia, com suas matas de babaçu, com suas lagoas piscosas, e com os vestígios ainda visíveis de suas aldeias de onde foram expulsos a bala.

Em 1.968, deixando minhas viagens fluviais e fixando-me em São Marcos, tomei maior conhecimento das aspirações dos índios pela sua volta ao Couto, aspirações que eu já tinha vislumbrado de 1.959 a 1.962, e pelas práticas encaminhadas pela Missão Salesiana de até então.

Após a visita do Sr. Ministro Albuquerque Lima, as garantias da FUNAI, minha visita ao Couto precedida pela do Delegado de Cuiabá, a apresentação pelo menos do projeto de Reservas (embora contrariando as aspirações dos Xavante), esperamos pelo desfecho, que porém desembocou no pedido do Sr. Presidente da FUNAI para eu estudar a proposta do Buker.

Aproveitei para ressalvar e satisfazer as exigências dos índios; como porém devia propor uma Reserva mínima e eu não conhecia bem a região e a história, julguei solucionar o problema amputando um mínimo da fazenda, entre o Rio Couto Magalhães e o Córrego Aldeia.

Quando, em conversa com os Xavante, dei fé do meu erro e fiz isso presente ao Sr. Dr. Queiroz, disse-me ele que aguardasse o Decreto para depois apresentar e conseguir as modificações.

Nesse interim a gerencia da fazenda, que pela chegada do Benedito já tinha transferido a sede desde o centro-leste para o centro-sul, bem perto da nova aldeia do Benedito, estava promovendo e multiplicando benfeitorias afim de dificultar a desapropriação, e recorria repetidas vezes à FUNAI em Cuiabá, em Brasília e no Rio de Janeiro para solicitar a remoção dos Xavante, aduzindo que:

a) Os índios estavam lá somente uns 3 anos, e que antes nunca, a memória dos antigos moradores, havia tido aldeamentos de Xavante por lá (mas já vimos a história de suas migrações, e existem fotografias duma aldeia próxima à famosa Lagoa, datada de 1.950 e antes, e muitos da ex-Fundação Brasil Central lembram isso). 
b) que os Xavante chefiados pelo Benedito saíram da Missão de São Marcos revoltados com os maus tratos dos Padres, e que portanto devia-se dar um jeito na Missão para os Xavante poderem voltar para lá.

c) que os Xavante tinham sido mandados para lá pelos Padres para se apossarem das terras para depois vende-las.

No ano passado bem duas vezes estive eu no Rio de Janeiro, no Departamento do Patrimônio, e inúmeras vezes em Brasília na Sede da FUNAI para recolher material cartográfico que possibilitasse um estudo sério das Reservas, para desmanchar todas essas insinuações e esclarecer os fatos.

Em dezembro, no dia imediato ao sepultamento do Marechal Costa e Silva, mostrei ao Diretor do Patrimônio Indígena no Rio, uma recente fotografia duma índia xavante da Missão Salesiana de Sangradouro, com 5 cicatrizes de feridas feitas por arma de fogo naquele longínquo assalto à aldeia, e tendo ainda no corpo uma bala. E vítimas assim ainda há muitas no Sangradouro.

O Sr. Diretor estava indo para uma reunião ministerial a respeito de genocídios e pediu-me essa fotografia e os informes, e deixou-me entregue ao encarregado imediato do Patrimônio para maiores esclarecimentos sobre as Reservas e sobre a comissão executiva do Ato Modificador do Decreto Ministerial das Reservas (na qual Comissões eu tinha sido incluído pelo Sr. Presidente da FUNAI.

Apresentou-me esse senhor esboços das 3 reservas com a descrição das fazendas dos invasores e sugestões de áreas livres para onde empurrar e encurralar os Índios.

Insistia eu sobre as reivindicações dos Xavante e sobre seus argumentos históricos, e então ele saiu-me com essa: "Padre, olhe, é melhor nos cedermos, aceitarmos os limites e os lotes por eles (os fazendeiros) propostos, porque muitos deles são militares, generais, brigadeiros, coronéis, etc., e eles mesmos é que vão providenciar as medições e garantir a terra aos índios contra outros invasores, e se nós insistirmos, então vai acontecer isto: eu vou ser despachado, o Sr. vai ser dispensado de sua colaboração, eles vão ficar mesmo com as terras, e os índios, não tendo mais quem os defenda, vão perder também estas terrinhas que lhes prontificam".

Isto, é claro, não me convenceu, mas desarmou-me no momento e emudeceu-me, limitando-me então a pedir cópia desses mapinhas para os estudar "in loco". 


\section{POSIÇÃO XAVANTE}

De todo o sobredito infere-se claramente a posição Xavante, e que se insistirmos sobre as Reservas já decretadas, com modificações e acréscimos, não é por um estéril idealismo étnico ou histórico, mas tão somente para ir ao encontro das necessidades desse povo e apresentar suas justas reivindicações as quais eles estão prontos conseguir a qualquer custo como já os Xavante de Pimentel Barbosa deram amostras, e os de Sangradouro e São Marcos protestaram-se ainda ultimamente: "Se não nos derem as nossas terras, iremos para lá e expulsaremos todos; morrer por morrer, vamos morrer lutando por elas".

...mas então o capítulo dos genocídios não estaria ainda encerrado?

.... Governo Federal eram o Diretor e o Inspetor e os Funcionários do SPI que com sua desídia anterior e durante e posterior abriram a porta e possibilitaram se multiplicassem e deixaram impunes tantos crimes.

.....Governo eram e são Governadores e Secretários, Prefeitos Municipais e Assessores que impunemente espezinham, e espezinham ainda a Constituição Brasileira em suas antigas e recentes redações, que despacham requerimentos de medição de terras dos Xavante, que assinaram e assinam Títulos de Propriedade e Transferência de Propriedade das Terras dos Xavante em benefício de Brasileiros e Estrangeiros em espoliação de seus já seculares legítimos donos,...... cegos diante de tantas injustiças e crimes e surdos aos tão altos e tão repetidos clamores deste povo que não foi extinguido e nem está aniquilado .......povo que não esta conformado com sua situação de vítima mesmo pranteada, mas que, mesmo sem saber do afama internacional a seu respeito e de seus irmãos de raça, quer reivindicar para si e desfrutar e frutificar os direitos que tanto Ihe propalam de "existência com suas instituições étnicas, sociais, culturais-lingüísticas, com seus sentimentos tribais e religiosos, "possíveis tão somente com a posse exclusiva de pelo menos dumas partes quantitativa e qualitativamente suficiente e historicamente sagradas do seu mais que secular território. 


\section{SOLICITAÇÃO E SUGESTÕES DA MISSÃO SALESIANA}

Esta já prolixa exposição dispensa uma anterior solicitação. Só um apelo ao Senhor Ministro que, ao findar sua embora breve visita às 2 Missões Salesianas para os Xavante em abril transcurso, deixou consignado no-Livro de Impressões: "Tive a melhor impressão das obras realizadas pelos Salesianos em São Marcos e Sangradouro tudo visando ao nosso indígena. Há esforço, compreensão, sacrifício mesmo. Parece-me que os resultados são satisfatórios. Esse trabalho merece e terá nosso apoio."

E a Missão Salesiana que desde longos anos não poupa trabalhos e sacrifícios naquele leste matogrossense em prol dos Bororo e à procura dos Xavante, e desde alguns anos assiste a mais da metade da tribo Xavante, reclama agora esse apoio para uma solução équa do problema afim de não assistir ao desmoronamento de toda a obra, ao esfacelo e extinção da tribo toda.

Sem meios materiais para cooperar na solução do problema que talvez dependa maximamente dos dispositivos legais e jurídicos em mãos de V. Ex. a , prontifica porém sua dedicação e experiência para a colaboração com a FUNAl, adiantando as seguintes sugestões:

\section{Reserva do Posto Pimentel Barbosa UIWEDEDZÉ}

A redação dessa Reserva saiu confusa por usar angulação diversa nas duas linhas secas, e inconsistente por não saber-se a que distancia do Rio das Mortes situa-se a Rodovia Xavantina-São Félix.

Portanto proporia os seguintes limites:

Marco 1. - - na Barreira de Areia, onde esta a atual aldeia do Posto Pimentel Barbosa, à margem esquerda do Rio das Mortes.

Marco 2.․ - na Barreira Água Limpa, junto à foz do Córrego Bacaba ou Água Limpa, uns $40 \mathrm{~km}$ em linha de ar ao NE do Marco 1.ํ, também na margem esquerda do Rio das Mortes, abaixo constituindo o mesmo Rio linha divisória.

Marco 3.- - na Rodovia Xavantina-São Félix, no cruzamento da linha seca que parte do Marco 2. rumo ONO 58. (usando sempre o quadrante com o "0" (zero) ao $\mathrm{NeS}$.

Marco 4.- na mesma Rodovia, ao Sul do Marco 3.․, no cruzamento da linha seca procedente do Marco 5. na margem esquerda do Rio das Mortes ao Leste do Marco 4.‥ 
A Rodovia será linha Divisória da Reserva, desde o Marco 3. ao Marco 4.․․

Marco 5.- na margem esquerda do Rio das Mortes, a $5 \mathrm{~km}$ por água acima (mas ao sul) da foz do Córrego Curuá ou Água Suja.

Ligar o Marco 5. com o Marco 1. margeando pela esquerda do Rio das Mortes rio abaixo rumo norte. Mais ou menos 280.000 hectares.

\section{Reserva do Posto Areões NORÕWEDEPA}

Também a redação desta Reserva saiu confusa porque as modificações não foram feitas de acordo com as indicações.

Portanto para esta Reserva proporia os seguintes limites:

Marco 1.-- bem no pontal entre os Rios das Mortes e Areões, onde esta situada a Sede do Posto.

Marco 2. - na margem esquerda do Rio das Mortes, bem defronte à barra do Rio Pindaíba, a uns 54 km em linha de ar ao NE do Marco 1.‥ O Rio das Mortes serve de linha divisória.

Marco 3.․- na Rodovia sobredita, no cruzamento da linha seca que parte do marco 2. rumo oeste 90 .

Marco 4.․- na mesma Rodovia ao SO do Marco 3.․․ junto à Ponte sobre o Rio Areões e à margem esquerda do mesmo Rio.

Também aqui a Rodovia serve de divisa.

Marco 5. na foz do correguinho Buriti (cuja cabeceira começa na estrada que desce a Rodovia via à aldeia) na margem esquerda do Rio Areões abaixo.

O trecho deste rio entre os Marcos 4. e 5. é linha divisória.

Marco 6. - - na ponta Sul da Barreira do Pirarara, na margem esquerda do Rio das Mortes, a uns 9 kms rio acima da Barra do Rio Areões, ligando os Marcos 5. e 6. com uma linha seca rumo SE 45.

Ligar o Marco 6. com o Marco 1.ํ descendo o Rio das Mortes até a foz do Rio Areões, fungindo aqui também o Mortes de divisor.

NB.- Quando em maio do ano passado propus a esses Xavante transferirem-se mais para o NE, pelo meio deste trecho do Rio das Mortes, recusaram-se terminantemente e daí resolveram invadir aquela derrubada encaminhada, ao NO, prontos a ceder a parte Nordeste da Reserva mas exigindo absolutamente para si todo o recanto Oeste que estava excluído na primeira redação, e que motivou as modificações mal interpretadas. Mais ou menos 100.000 hectares. 


\section{Reserva do Couto Magalhães NORÕTSU'RÃ}

Com esta tão diminuta Reserva é que os Xavante não ficaram por nada satisfeitos; os do Couto com o propósito de nunca saírem de lá mesmo pressionados pela fazenda, e decididos a se meterem pela fazenda toda; os de São Marcos e Sangradouro impacientes por invadirem e expulsarem todos os civilizados da fazenda e arredores, por qualquer meio.

A redação desta Reserva deve agora subir uma modificação para ampliação, para incluir as aldeias de onde foram expulsos, e se assim poderemos talvez conseguir que se satisfaçam e sosseguem.

Portanto estes os limites que acho "conditio sine qua non":

Marco 1.- - na ponta da cabeceira do Córrego Aldeia, afluente de direita do Rio Couto Magalhães.

Marco 2.-. na barra do córrego Aldeia com o Rio Couto Magalhães, servindo o mesmo córrego de linha divisória.

Marco 3.-. na ponta da cabeceira esquerda principal do Rio Couto, ligando os Marcos 2. e 3.․ com uma linha seca rumo Oeste Sul Oeste de mais ou menos $45 \mathrm{~km}$.

Marco 4.- - na ponta da cabeceira direita principal do mesmo Rio, ligando os Marcos 3. e 4. com uma linha seca rumo Sul de talvez $20 \mathrm{~km}$.

Ligar os Marcos 4. e 1. com uma linha seca rumo EFE de talvez $25 \mathrm{~km}$ Dada a inviabilidade de incluir a Reserva de 10.000 hectares de junho de 1.967, ficaria a mesma à disposição do Estado. Mais ou menos 75.000 hectares.

\section{Reserva do Pontal Couto Magalhães-Coluene}

Quando estive no Departamento do Patrimônio Indígena no Rio de Janeiro em dezembro, disseram-me que havia estado lá o Sr. Hélio Buker com um grupo de Xavante que reclamavam para si essa região, e que portanto não precisavam mais pensar na Reserva que invadia a "Fazenda Xavantina".

Mas acontece que os Xavante que o Sr. Buker levou ao Rio eram dos Postos Batovi ou Simões Lopes, não portanto os residentes atualmente no Couto e tampouco os de São Marcos ou de Sangradouro que reivindicaram há tempos as terras invadidas pela Fazenda Xavantina e outros.

Sabemos aliás, por boca dos mesmos Xavante do Batovi em visita às nossas Missões, que eles realmente pleitearam aquela região, no intuito de boa parte deles voltar a morar à direita do Coluene para estarem mais próximos de seus parentes. 
Vai aqui portanto indicada também esta Reserva, caso o Sr.Buker ainda não tenha encaminhado outro projeto:

Marco 1. -- na Margem esquerda do Rio Couto Magalhães, no seu cruzamento com o Paralelo 14.

Marco 2.-- na confluência do rio Couto Magalhães com o Rio Coluene, servindo este trecho do Couto como linha divisória.

Marco 3.-- na margem direita do Rio Coluene, no cruzamento com o Paralelo 14, servindo também este trecho do Rio Coluene como linha divi-sória.

Ligar os marcos 3. e 1.ㅇ com uma linha seca rumo Leste de uns 40 km aproximadamente, 70.000 hectares, ao que parecer na maior parte sem donos e posseiros, portanto sem contestação.

Quem não vai ficar satisfeito vai ser o José do Batovi, o chefe que veio daquele Posto, há anos, com um bom grupinho, e que morava naquela aldeia do afluente do Coluene.

\section{Reserva da Missão Salesiana de São Marcos}

Mesmo que uns 300 Xavante desta Missão passem à Reserva Couto Magalhães (e eles desejam ter lá também a assistência dos Missionários Salesianos), assim mesmo 500 e mais Xavante ficariam apertados demais dentro dos 14.000 hectares que sobraram dos, 25.000 hectares da Reserva concedida em 1.918-1.921 pelo então Governador do Estado de Mato Grosso.

Em 1.961, em seguida às contestações dos invasores à revelia dos Padres, o Governo Estadual pediu à Missão cedesse uma parte para os pequenos posseiros, e lá cortaram 11.000 hectares cuja maior parte, na realidade beneficiou fazendeiros que vendiam suas próprias terras.

A repetição aborrecida de injunções e proibições e ameaças por parte dos circundantes fez com que alguns dos nossos Xavante pensassem em voltar ao Couto Magalhães, e os demais mostrassem aos missionários a necessidade de ampliar um pouco mais sua reserva de caça e pesca e coleção de frutas aí mesmo em São Marcos.

A Missão Salesiana portanto, lembrando também que ela mesma já tinha iniciado uma colônia de atração à beira do Rio das Mortes além o Rio São Marcos, quando os civilizados ainda estavam a mais de 100 kms na retaguarda, e que lá mesmo o SPI instalou seu Posto por uns dois anos em época mais recente, e fazendo presente que os Xavante "Ab imme-morabili" percorriam toda essa região à procura de seu suprimento, e que dentro da diminuta reserva a situação é de uma vez insustentável, 
propõe ampliar a Reserva recuperando o que foi compelida entregar em 1.961, abrir mais um pouco sua chegada ao Rio São Marcos, anexar a região toda abrangida entre os Rios das Mortes, São Marcos e Córrego Dom Bosco, e mais uma beirada fronteira na margem esquerda do Mortes.

Já é pacífico que toda essa Reserva passaria a ser Reserva da FUNAI, mesmo com nomenclatura e assistência da Missão Salesiana.

Então poderia ser assim configurada:

Marco 1.-. no alto Morro da Providência, no lugar do marco 5. da antiga gleba.

Marco 2.-- na margem direita do córrego Boqueirão, no lugar do marco 1.ำ da gleba, unindo os 2 Marcos com uma linha seca de 3.600 metros rumo NW 38.30'.

Marco 3.-- na margem direita do Boqueirão, confrontante a barra da cabeceira do Retiro, afluente esquerdo do Boqueirão, a uns 12.000 metros do marco 1. rumo ENE córrego abaixo, servindo o córrego como divi-sa.

Marco 4. - - no alto do paredão que sobrepuja o galho Leste da dita cabeceira, sendo a divisa formada pela veia d'água e por linha seca até amarrar o marco 4.․․

Marco 5.- - na margem esquerda do Rio São Marcos, amarrando os 2 Marcos com uma linha seca que parte do marco 4. rumo NE 65. de uns 11.000 metros.

Marco 6. - - na barra do rio São Marcos, com o Rio das Mortes, constituído aquele rio a divisa neste trecho.

Marco 7.- - na margem esquerda do Rio das Mortes confrontando a barra do Rio São Marcos.

Marco 8. - - na margem esquerda do Rio das Mortes, ao NE do Marco 7.․, na barra do córrego afluente de esquerda deste Rio, desaguando nele abaixo (ao Norte) do Córrego Dom Bosco, sendo esta linha divisória de uns $30 \mathrm{~km}$ parte em linha seca e parte pelo córrego sobredito desde o ponto do cruzamento.

Marco 9. - - na barra do Córrego Dom Bosco, afluente de direita do Rio das Mortes, por esta água acima rumo ao sul constituindo este trecho do Rio das Mortes a divisória.

Marco 10.- na cabeceira extrema do Dom Bosco, constituindo o mesmo córrego a linha divisória.

Marco 11. - na cabeceira extrema do Rio São Marcos, ligando os 2 Marcos com uma linha seca de uns $6 \mathrm{kms}$ rumo SUL.

Marco 12.․ - na margem esquerda do Rio São Marcos a 1 km de distancia da Usina Hidroelétrica da Missão Salesiana, rio acima, servindo este trecho do Rio São Marcos como linha divisória. 
Marco 13. - - na margem esquerda do Rio Barreiro, na barra do Córrego Diamante (antigo Fundo), no lugar do marco 3. da gleba, unindo estes 2 Marcos com uma linha seca de uns $18 \mathrm{~km}$ rumo SW 54.

Marco 14.- na margem esquerda do Rio Barreiro, rio acima, no lugar do antigo

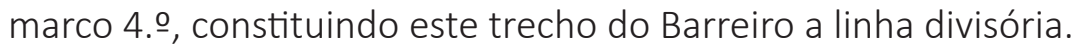

Ligar o marco 14. com o marco 1. com uma linha seca de $12 \mathrm{kms}$ rumo NW 52., a mesma da gleba, como também a dos Marcos 1. e 2.‥ Uns 130.000 hectares, sendo 25 da antiga gleba.

\section{Reserva da Missão Salesiana de Sangradouro.}

Como já supra explanado, a terra da Missão Salesiana de Sangradouro é de propriedade da Missão Salesiana de Mato Grosso, pois comprada de terceiros em várias épocas, a começar pelo 1.․ lote medido em novembro de 1.893 pelo então Engenheiro Militar Cândido Mariano da Silva Rondon, para servir de base às tropas e comboios que vindo de Cuiabá iam suprir a Missão Salesiana dos Bororo na região Merúri.

Mais tarde abrigaram aí grupinhos de Bororo vindos dos garimpeiros ou das aldeias dos Rio Vermelho e São Lourenço, famintos e doentes, e quando restabelecidos e bem dispostos lá iam, eles sumindo.

Mais tarde a Missão abriu suas portas também às crianças sertanejas, e já em 1.938 eu lá lecionava a mais de 30 meninos, e as Irmãs a outras tantas meninas, e foram aumentando com o avançar dos pioneiros, tanto que em 1.957 já era uma procuradíssima Escola Agrícola Rural.

No fim do ano letivo 1.957 a Missão Salesiana encerrou definitivamente os internatos masculino e feminino para sertanejos afim de prontificar todas suas instalações e pessoal ao atendimento dos Xavante chegados durante aquele ano na maior das necessidades.

Assim a Missão Salesiana sacrificou o atendimento à sociedade envolvente, que porém pressiona cada dia mais a reabertura.

Também a terra da Missão não passa de uns 10 ou 11 mil hectares, e o dilagar dos atuais 400 e mais Xavante para a caça e coleta de frutas provoca reclamos insistentes e ameaças por parte dos confinantes.

Há uns 130 Xavante que pretendem voltar para sua terra no Couto Magalhães logo consigam a Reserva tanto reclamada e prometida, e caso não consigam o que sonham, estão prontos à luta. 
Mas os outros mais que 250 ficariam, e precisam de maior extensão territorial de propriedade exclusiva deles, mormente ao norte da Missão, aquém e sobretudo além o Rio das Mortes, sua Região da caça "ab immemorabili".

Por isso a Missão Salesiana avança a proposta duma Reserva para os Xavante anexa à Terra da Missão (para a Missão poder reabrir suas portas aos civilizados), pois próximo ao Rio das Mortes entre o Rio Sangradouro e o Córrego dos Porcos (ambos com quedas d'água é um ótimo lugar para citar condições para a transladação paulatina dos Xavante.

Esses seriam os limites mínimos propostos:

Marco 1.-. na linha telegráfica, no limite da terra da Missão, ao oeste da sede da mesma.

Marco 2.․ - na margem direita do córrego Alminhas no cruzamento da linha telegráfica, ao $\mathrm{W}$ do marco 1., sendo o Telégrafo o divisor.

Marco 3.․- na barra do córrego Alminhas (afluentes da direita com o Rio das Mortes ao Norte do marco 2.ํ, o córrego será divisor.

Marco 4.-- na margem esquerda do Rio das Mortes, defronte a barra do córrego Sangradorzinho (afluente de direita do Rio das Mortes) rio acima, ao W do marco 3. $\circ$, sendo este trecho do rio divisor.

Marco 5.-- no cruzamento da linha seca com o paralelo 15., partindo o mesmo do marco 6. ․ rumo norte.

Marco 6. -- ao Leste do marco 5. ․ no cruzamento da linha seca com o paralelo 15., a qual sobe rumo norte partindo da barra do Córrego Macacos (Marco 7.ํ). A linha seca sobre o paralelo 15. será a linha divisória.

Marco 7.․ - na margem esquerda do Rio das Mortes defronte ao córrego Macacos, afluente de direita do Rio das Mortes.

Marco 8. - - na barra do Córrego dos Porcos, afluente de direita do Mortes, ao oeste do Córrego Macacos, servindo este trecho do Rio das Mortes como linha divisória.

Marco 9.- no cruzamento do Córrego dos Porcos com a linha telegráfica ao sul do Marco 8.․․, servindo este córrego como divisor.

Marco 10.- na linha telegráfica na divisa Leste da Terra da Missão, unindo os Marcos 9. e 10. com uma linha seca.

O perímetro da terra da Missão ao norte da linha telegráfica, desde o marco 1. ao marco 10. será a linha divisória da terra da Missão com a Reserva para os Xavante do Sangradouro assistidos pela Missão Salesiana. Uns 140.000 hectares. 
Uma verificação sumária destes limites, sem mesmo demarcar, e o levantamento também por cima dos proprietários e posseiros existentes nas áreas indicadas deveriam ter toda prioridade na pauta dos trabalhos, pois urge solucionar o problema, estando já pela metade de março, quando em abril e maio já se iniciam os desmatamentos. 


\section{CONCLUSÃO}

Ex.mo Sr. Ministro, não sei se cheguei a pôr em evidência a idéia mestra, se consegui fazer ressaltar, destacar, emergir a gravidade do problema e o tipo de solução improrrogável e necessária afim de se fazer justiça à tribo dos Xavante, custe o que custar.

No Parque Nacional do Xingu menos de 1.000 índios, cuja maioria vivem no rio e do rio, têm à sua disposição uns 2.000.000 (dois milhões) de hectares de terra.

É verdade: o Parque Nacional não é somente Indígena, portanto esta outra e primária finalidade justifica sua amplitude.

Dos 2.000.000 (dois milhões) de hectares que o Estado de Mato Grosso com manhosa liberalidade prontificou ao Xavante em 1.950, a este índio andarilho, caçador infatigável pelos campos e chapadões, por lei estadual só sobraram 3 irrisórias e simbólicas parcelas de 10.000 (dez mil) hectares cada uma.

Mas de símbolos ninguém vive e menos ainda estes 2.300 Xavante.

É verdade, a Missão Salesiana "dispôs" da irrisória e simbólica parcela de Santa Terezinha (em 1.962), tornada insustentável como foi ilustrado, para provar aos Xavante abrigados em São Marcos num momento crítico da Missão Salesiana sem nenhum vislumbre de apoio e de auxílios por parte do Serviço de Proteção ao Índio.

Agora a Missão Salesiana, consciente da realidade nacional de expansão e aproveitamento do Território Nacional, ciente da "Situação" dos desbravadores, sem esquecer porém a realidade indígena, advoga para seus Xavante (digo seus porque assiste a mais de metade dos 2.300 Xavante atuais, e faz causa comum com a FUNAI no espírito de colaboração promovido por V. Ex. aㅗ advoga, digo, para a Nação Xavante menos da metade (uns 800.000 hectares) do território de que fora agraciada ainda antes de ser pacificada, a qual partilha já era tão somente a décima parte daquilo que havia um século desfrutava soberana.

Se "omnibus perpensis" for achada uma cabal solução mais satisfatória e menos utópica, estaremos prontos a continuar nossa colaboração em prol do Índio Xavante e para a glória do Brasil.

Pedindo "venia" pela delonga e pela insistência em assunto tão cruciante, renovando os protestos de simpatia e consideração pela pessoa e obra de V. Ex. a e augurando-Ihe as luzes e dádivas divinas para o árduo trabalho que lhe incumbe.

Em nome da Missão Salesiana de Mato Grosso devedora a V. Ex. a da estima e afeto que lhe leva,

Brasília, 10 de Março de 1.970. 


\section{DOCUMENTOS ANEXADOS}

1.- Foto de mulher Xavante baleada.

2.- Cópia do Decreto Estadual no. 903 de 28 de março de 1.950.

3.- Cópia do Decreto Ministerial no. 25.212 de 23 de setembro de 1.969.

4.- Cópia dum esboço da Reserva de Pimentel Barbosa decretada.

5.- Cópia dum esboço da Reserva de Areões decretada.

6.- Cópia dum esboço da região Couto Magalhães relativa à Reserva.

7.- Cópia de parte do Mapa Cadastral do Município de Barra do Garças.

8.- Cópia do título de domínio da Reserva São Marcos.

9.- Cópia dum dos autos de medição por Rondon na Região Sangradouro.

10.- Cópia dum dos Títulos da região Sangradouro (Lote Sangradouro Grande).

11.- Cópia dum dos Títulos da região Sangradouro (Lote Rib. das Malas).

12.- Cópia dum dos Títulos da região Sangradouro (Lote Lagoa Feia).

13.- Cópia dum Mapa da região Sangradouro, feito por Rondon.

14.- Cópia da Planta das Terras da Missão Salesiana de Sangradouro (1.956).

15.- Cópia do Mapa extraído do Mapa USAF ao Milionésimo. 
Reserva para Uso dos Índios Xavante as Terras pelos mesmos ocupadas, só que os aldeamentos das cabeceiras do Rio São João, ao Norte, o do Rio Couto Magalhães, ao sudoeste, ficaram fora desta Reserva, e isto ainda antes de serem pacificadas.

Ainda mais, a Reserva, ao sul, já estava cortada pela picada Xavantina-Roncador-Xingu, da Fundação Brasil Central que operava na região havia alguns anos, e já em abril de 1.952 os tratores abriam a estrada para o Garapú.

Tivessem feito logo duas Reservas, abrigando todos os aldeamentos daquele tempo, e deixando um larguíssimo corredor no meio, teriam evitado tantos crimes, tantos aborrecimentos.

MINISTÉRIO DO INTERIOR

FUNDAÇÃO NACIONAL DO ÍNDIO - FNI

Decreto no. 903, de 28/3/1950.

RESERVA PARA USO DOS ÍNDIOS XAVANTES AS TERRAS PELOS MESMOS OCUPADAS, NO MUNICÍPIO DE BARRA DO GARÇAS.

O GOVERNADOR DO ESTADO DE MATO GROSSO, usando da atribuição que the confere o artigo 33, item I, da Constituição do Estado, e tendo em vista o que consta do processo no.767/50, da Diretoria do Expediente do Governo, decreta:

Art. 1- Fica reservada para uso dos "Índios Xavante" no município de Barra do Garças, a área de terras pelos mesmos ocupada, com os seguintes limites: partindo da barra do Rio Noedori, no Rio das Mortes ou Rio Manso, por esse abaixo até a Barreira da Bocada, deste ponto por uma linha seca, no rumo de N.W. 58. até encontrar a linha de 53. de longitude; deste ponto com uma linha no rumo de S.W. 23. 000. até encontrar o ponto de intercessão da linha determinando o 53. de longitude com o Rio Noedori, e deste ponto pelo Noedori abaixo até a sua barra no Rio Manso ou das Mortes, ponto de partida.

Art. 2- As terras ora reservadas serão medidas e demarcadas pelo Serviço de Proteção aos Índios, dentro do prazo de dois anos.

Art. 3- Revogam-se as disposições em contrário. 
Palácio Alencastro, em Cuiabá, 28 de Março de 1.950.

129. da Independência e 62. da República.

Arnaldo Estevão de Figueiredo

Rosário Congro.

N.o 3 Cópia do Decreto Ministerial no. 25.212 de 23 de Setembro de 1.969, criando as 3 Reservas.

Em seguida um exorto do "O Estado de São Paulo", mas sem data, referindo O Ato Modificador.

No cartório de Bens Imóveis etc. de Barra do Garças, Município ao qual pertencem as áreas em pauta, encontrei pregado na parede para todos verem, um mapa das Reservas, o Decreto criador, e exortos de jornais referentes ao Ato Modificador. 


\section{Decreto no. 65.212 - de 23 de Setembro de 1.969.}

\section{(Cria as Reservas indígenas que discrimina, no Estado de Mato Grosso).}

Os Ministros da Marinha de Guerra, do Exército e da Aeronáutica, usando das atribuições que lhes confere o art. 1. do Ato Institucional no. 12, de 31 de agosto de 1.969, combinando com o art. 83, item II da Constituição, decretam:

Art.1. - Ficam reservadas às tribos Xavante do Rio Couto Magalhães, do Rio Areões e do Rio das Mortes, para os efeitos previstos no art. 186 da Constituição, as áreas adiante discriminadas, situadas no Estado de Mato Grosso:

a) - partindo da nascente do rio Couto Magalhães até a sua confluência com o Córrego da Aldeia; subindo o Córrego da Aldeia até à sua nascente; daí uma linha seca para Noroeste, até à nascente do Rio Couto Magalhães;

b)- partindo da confluência do rio Areões com o Rio das Mortes, descer o Rio das Mortes, no rumo Nordeste, até a confluência com o Rio Pindaíba; daí uma linha seca rumo ao Oeste, de 50 kms; dai uma linha seca rumo Sudoeste até o Rio Areões; daí uma linha seca rumo sudeste até encontrar a Barreira do Pirarara à margem esquerda do Rio das Mortes; daí descendo o Rio das Mortes até a confluência com o Rio Areões;

c)- partindo da confluência do córrego Bacaba com o Rio das Mortes, uma linha seca rumo Noroeste (111.), de 60 kms (Serra do Roncador); desse ponto, uma linha cerca, rumo sul (180.), de 76 Kms de extensão; daí seguir rumo Nordeste (69.) até encontrar a cabeceira do rio Curuá. Desse ponto pelo curso do rio Curuá, até a sua confluência com o Rio das Mortes, seguindo por este, rumo Nordeste, até o ponto de partida.

Art. 2.-- A Fundação Nacional do Índio promoverá as medidas necessárias no sentido de criar, nas reservas discriminadas no art. 1o condições para que nelas sejam localizados os grupos indígenas da tribo mencionada, espaços fora de seus limites.

Art. 3.-.- Fica facultado à Fundação Nacional do Índio, no exercício de poder de polícia conferido pelo art. 1o., item VII da Lei no. 5.371 de 5 de dezembro de 1.967, requisitar a cooperação da Polícia Federal, no sentido de que sejam impedidos ou restringidos o ingresso, o trânsito ou permanência de pessoas ou grupos cujas atividades sejam julgadas nocivas ou inconvenientes, ao processo de assistência aos índios, nas áreas reservadas.

Art. 4.-. Este Decreto entrará em vigor na data de sua publicação, revogadas as disposições em contrário.

Brasília, 23 de setembro de 1.969; 148. da Independência e 81. da República. 
(a)Augusto Hamann Rademaker Grunewald

(a)Aurélio de Lyra Tavares

(a)Márcio de Souza e Mello

(a)José Costa Cavalcanti

\section{(De “O Estado de São Paulo" poucos dias depois)}

Os Ministros Militares, no exercício da Presidência da República, assinaram ato que modifica o Decreto no. 65.212 de 23/9/69, fixando normas para a determinação das áreas a serem habitadas pelos índios Xavante. O Ministro Costa Cavalcanti, do Interior, assim justifica as modificações propostas ao decreto 65.212, que dispõe sobre reservas indígenas no Estado de Mato Grosso:-"A Fundação do Índio, órgão vinculado a este Ministério, vem procurando delimitar as áreas reservadas aos silvícolas, a fim de dar melhor cumprimento ao preceito constitucional contido no art. 186 da Magna Carta. Sem ter em vista qualquer modificação na política indigenista brasileira, o projeto ora apresentado visa regular o estabelecimento da situação e dos limites das áreas de terra a serem reservadas e que no decreto 65.212, "supramencionado", não ficaram livres de eventuais contestações.

\section{Sobre o autor:}

George Lachnitt: Salesiano, diretor do Núcleo de Estudos e Pesquisas das Populações Indígenas (Neppi/UCDB), responsável pelo Centro de Documentação Indígena da UCDB e Editor da Revista Tellus. E-mail: tellus@ucdb.br

\section{Recebido em 31 de julho de 2017}

Aprovado para publicação em 11 de setembro de 2017 
